DOI https://doi.org/10.36059/978-966-397-203-9/83-104

\title{
ON THE DYNAMIC OF PUBLIC SPEAKING IN THE WORLD AND UKRAINE
}

\section{Ovchynnikova A. P.}

\section{INTRODUCTION}

The ability for deliberate and comprehended communication is the first and foremost feature which makes us, human beings, different from all the other creatures living on our planet. Since a man learnt to use the word (spoken and written) in order to convey ideas, and thus influence the community around him, speaking has been the tool and the weapon no less powerful than a hammer or a sword. It is verbal communication which can start wars and lead to peaceful agreements, which may ruin peoples' lives and let them achieve unbelievable success and prosperity, which can cure one's hurt feelings and make a person feel distraught. A spoken (or written) word can be used both for good and for bad, so it is essential to know how to direct this unique power for good purposes.

We often treat the ability to speak as an innate gift that we were born with and that does not need any refinement. However, there is hardly any adult who has never found him/herself in a situation when it was necessary to make a speech and who has not felt anxiety in such a case. On the other hand, everyone can recall listening to someone's speech and having to put a lot of effort in order to hear (or/and understand) what the orator is talking about. Remember when you were listening to a politician, lecturer or even a well-known TV personality's speech, and had to try hard to get the idea: why did this happen? Sometimes we could not take the message in easily due to the speakers' poor enunciation or to their very soft voice or unusual manner of talking. In other case it was really impossible to get the gist because the talk was not organized properly, or there were not enough examples to support the main speaker's points. We can think of a lot of reasons why comprehension of a speech was not complete, but if one wants to become a successful speaker and avoid making these errors in presentations, he/she should learn HOW to speak successfully.

Good orator's skills are vital for politicians or lecturers, but not only for them. We all heard that people judge by appearance, and while your looks is what the others first see about you, your speech is "the mind's 
appearance", it is what allows people to make some first conclusions about your personality and inner world. We never get the second chance to make good first impression: whenever you meet people for the first time, you have to say at least a couple of words, so the people first see you - make some judgments from the way you look and then hear you get some idea about what kind of person you are.

It is even more essential when you present your ideas to a group of listeners - audience (have to make a public speech). The way you pronounce the words, have (or do not have) eye-contact with the listeners, put the ideas in order, give some supporting information, affects the audience's perception of your speech and you as an orator. Mastering public speaking skills provides anyone with the great advantage of open and effortless communication, as in this day and age, communication is one of the most important and crucial ingredients to success.

It is undeniable that speech communication has always been an essential part of the humanity progress. Along with such not less important aspects of mankind's development as scientific and technical advancement, improvement and sophistication of speaking skills lead people forward to the present state of civilization. Public speaking is studied and taught in lots of educational institutions all over the world. The significance of the academic study of speech, for example, is illustrated by the fact that in 1978 in the USA speech training was mandated by the federal government, in the Primary and Secondary Education Act $[9$, p.5].

Nowadays it is time for individuals to stop viewing public speaking as something that happens as frequently as a holiday, and to recognize the opportunity that exists for communication to drastically improve their lives, grow their business, help them land better jobs, enhance their relationships. Thus, the skills of good speaking have become vital for any educated person, no matter which sphere he/she is occupied in.

Public speaking is one of the liberal arts; its subject is structure and proper use of speech in order to carry out social coordination, and express opinions. There are two main aspects of studying this subject which, despite their principle difference, are closely connected and constantly affecting each other: 1) historical aspect or learning what the mankind has done in the sphere of speaking publically (analysis of experience gathered by generations), 2) practical aspect or training, acquiring skills necessary for becoming a successful speaker. 
So, studies on public speaking, first of all, imply introduction students to the spiritual heritage of the remarkable speeches accumulated by previous generations. In this great conception, the study of human speech is the study of such disciplines as the ethics, practical philosophy, and most eloquent expressions of the human spirit: the essence of the liberal arts. The great creative potential of public speeches is revealed by the experience of many generations; the historical view on this subject allows us to see both its contemporary pragmatic value and its immanent contents which have been accumulated in the art of speaking since it was born in the world of an Ancient man.

However, getting to know the best samples of the public talk that proved their importance and influence on listeners over the years, learning the genesis of speech communication and analyzing the role of outstanding speakers in the history of the world not only allows us to understand importance of public speaking but also enables us to learn the technicalities of making our own speeches, i.e. of being "vir bonus, decendi peritus" (The good person, speaking well) (Cicero) [6].

So, on the other hand, the academic studies on public speaking involve analyzing HOW TO, ACTUALLY, MAKE SUCCESSFUL SPEECHES. In this aspect one should learn how to organize the material chosen for the speech, which techniques to use to make your talk impressive, how to practice the talk in order to present it successfully or what to do to combat your stage fright and other [8]. Moreover, to be an expert in speech making one should also become a sophisticated receiver of public talk.

\section{Evolution of Public Speaking in the Ancient World. Rhetoric in Ancient Greece and Rome}

\subsection{Prominent orators in Ancient Greece}

The basis for public speaking as the social phenomenon was created by the need for public discussion as the way of solving problems that are significant for the society.

Vital condition for genesis of the speech art was the emergence of democratic rule along with the citizens' participation in the political events of a country. That is why the crucial moments in the life of nations were also the most prolific time for the progress in public communication. The necessity for good public speakers increases whenever it is essential for the great number of people (the society) to 
take part in making important historic decisions. Thus, we see the appearance of public speaking as art in Ancient Greece and the growth of interest in public talks at the time of the Renaissance, when the wide mass of people were involved into social changes.

The art of speaking in public originated, obviously, at the epic times when there was a need for retelling the myths to the wider circle of listeners. However, it is impossible to see any theoretic analysis of this art earlier than Rhetoric as a sphere of mental activity emerged.

According to A.A. Averintsev, the phenomenon which we normally refer to as culture was called Pandea (i.e. upbringing or rearing) by the ancient Greeks, and in this word they indicated the sum of all the skills that a child was trained [1]. The core of pandea consists of two forces which, though contradict each other, are in the constant interaction, contact; they are: nurturing the thought, or teaching of philosophic search of truth, and nurturing the word, that is teaching rhetoric, in order to acquire persuasiveness. So, philosophy and rhetoric which were placed in the centre of culture by the Ancient Greeks have more in common than we could imagine at the first sight: they have one root that derives from the archaic mental-speech culture.

In Ancient Greece public speaking flourished in the 5-th century B.C., then it became an essential part of public life and means of achievement of fame and prosperity. The famous speakers were known by everyone and everybody wished to acquire good speaking skills.

At the initial stage public speaking was influenced by the works by Aristotle, Gorgeus, Lisyus, Isocrates, and Demosthenes.

The earliest attempts to develop Rhetoric were made in Sicily, where the first theories of judicial speech and of the ways and typical methods of argumentation were formulated. The purpose of argumentation was to demonstrate the "truthfulness" of presentation in the dispute to the benefit of one of the conflicting sides.

The crucial role in creation of the theory and forms of the prose writing style is attributed to a Sicilian sophist Gorgius (about 483-375 B.C.). He is credited with making the first code (set of regulations) of rhetoric techniques, systemizing the rules for making orations and writing the first "guide for speech-making". As all sophists, Gorgius believed that the essential task of a speech was to achieve some practical effect, regardless of whether it (a speech) resulted in truthful or false conclusions at the end. He supposed that the aim of the Art of Speech is deception, "making believe" or illusion of creating an unrehearsed, impromptu speech at the sight of the audience. A speech should enchant its listeners by means of style. Style is a range of 
techniques and rhetorical means used in order to express an idea within communicative practice. The most characteristic features of Gorgius' style were numerous metaphors or so called "Gorgius's figures of speech". He also employed the method of breaking a sentence into the parts, related to each other on the basis of contrasting ideas and/or repetitive sounds, especially often at the end of each part so that they could form a kind of a rhyme. So, he chanted his speeches, used nonverbal means of communication and directed his prose to a poetic, rhythmical talk. Gorgius' speeches belong to epideictic type.

Lisius (459-380 B.C.) was a qualified "logographer", i.e. a person who wrote speeches for the others, used to make speeches "on the order". He was the first to pay attention to the necessity for making reference books of typical orations and pioneered structuring speeches. He defined such stages of a judicial oration as:

1) introduction, aimed on getting the judges' approval and attracting their attention;

2) presentation of the factual part of a case;

3) proof of the accuracy in presentation of facts;

4) disputing with an opponent, who must be demeaned by any means (here we face the problem of culture)

5) conclusion that should contain the answers to all the questions raised in the speech (summarizing).

Isocrates (436-338 B.C.) was Gorgius' disciple. Due to his quiet voice he could not be a successful orator, so Isocrates decided to become a logographer. Later he founded a school in Athens where he taught public speaking. He shaped the scheme which was used to write biographies: 1) glorification of the person's ancestors; 2) the biography itself; 3) description of the personality; 4) apotheosis (veneration) of the person.

Demosthenes (384 - 322 B.C.) was a prominent orator, as a child he had a very weak, indistinct voice and mispronounced some sounds, so his first public talks were predestined to failure. However, thanks to hard work and determination, Demosthenes managed to turn his weaknesses to the advantages. There is a legend that he practiced reciting poems standing at the sea shore shouting as loud as he could into the winds of the Aegean Sea; he also loaded his mouth with pebbles to practice articulating around them.

He placed a special accent on intonation, Plutarch in the speaker's biography recalled the anecdote: "It was said that once a person came to Demosthenes and asked to present him in the law court as he had been assaulted. "Nothing like that has happened to you,"- the orator doubted. 
Then the requester raised his voice and shouted outraged: "How can you say it has not happened to me!" - "Now, I hear the voice of the humiliated one," - Demosthenes said."

His speeches were characterized with dynamism, humour and appropriate argumentation. He exploited all the expressive means which were accumulated in Greek public speaking tradition, skillfully finding proper style for any circumstances.

Aristotle (384-322) was the greatest Greek philosopher who treated rhetoric as a special form of art and knowledge that deserved profound analysis. He described some aspects of rhetorical art, such as logical and political ones. It was the time when the term rhetoric was first applied to the art of persuasion. On the whole, Aristotle defined rhetoric as the ability to find methods of persuasion with regards to any possible subject. He distinguished several types of speeches and means of persuasion which depended on the speaker's moral features, the audience's disposition, the character of a talk and other. Aristotle divided special speaking techniques to psychological and logical ones. $\mathrm{He}$ supposed that success of a speech is guaranteed not only by an orator's talents and contents of a talk, but, what is more important, by the techniques used by a speaker.

In the early dialogue entitled "Grullos" Aristotle put forward the argument that rhetoric cannot be an art, but the evidence for this in the dialogue is to tenuous to support any strong conclusions on Aristotle's idea of Rhetoric. What has come to us are the three books which are known as "Rhetoric". The principles of effective speech-making were presented in the third book of Aristotle's book.

The structure of the "Rhetoric" parts 1 and 2 is determined by two tripartite divisions.

The first division consists in the distinction of the three main means of persuasion. A speech can persuade the audience through the character of a speaker through the emotional state of the listeners or the argument itself (logo).

The second division concerns three aspects of public speech: the deliberative speech (it takes place in the assembly), the judicial speech (which takes place in the court), and the epideictic speech (the speech which praises or blames someone, it tries to describe the deeds of a person as honorable or shameful ones).

The third book discusses the several questions of style. According to Aristotelian idea of a good style, the style in the speech should be clear in a manner that is neither too banal nor too dignified, but appropriate to the subject matter of the speech. The use of usual and common words is 
fundamental for speech. However, to make a speech pleasant and avoid banality, the author should reasonably exploit non-familiar means, such as metaphors and borrowed words.

Aristotle writes that rhetoric is closely connected to dialectics. The rhetorician who wants to persuade by arguments can adapt most of the dialectical equipment. Nevertheless, persuasion that takes place in the face of public audience is not only a matter of arguments and proofs? But also of credibility and emotional attitudes, which make it different from dialectics. While dialectic tries to test the consistency of a set of sentences, rhetoric tries to achieve persuasion of a given audience.

Aristotle defines a rhetorician as someone who always manages to be persuasive. The rhetoric is centered on the rhetorical kind of proof, or the enthymeme. Enthymeme is a form of a "syllogism", deductive arguments a set of sentences in which some sentences are premises and one is the conclusion. Since people are most strongly convinced when they suppose that something has been proven, there is no need for the orator to distract the audience by the use of emotional appeals. Aristotle's rhetoric relies on the project of persuasiveness of pertinent argumentation.

After Aristotle the term rhetoric was used with reference to both practical speaking skills and to a special area of theoretic knowledge.

By the 3-rd century B.C. the contents of Rhetoric as a separate discipline was outlined. Rhetoric theory included 5 parts.

Part 1 prescribed how to select the material for a speech (to use typical ideas, common points, and "general" thoughts);

Part 2 explained how to organize this material (structure the speech);

Part 3 was teaching of the styles of speech, ways of speech enrichment;

Part 4 advised on how to memorize the speech;

Part 5 taught artistic speech presentation, performing art (the students wrote texts on behalf of famous people or mythological heroes, created orations in admiration of a place or a person, competed in recitals etc.).

\subsection{Famous orators in Ancient Rome:}

\section{Cicero and T. and G. Gracchus}

In the 2-nd century B.C. Rome was famous for the exceptional public speakers and theorists of rhetoric, such as Cicero, Quintilian and T. and G. Gracchus.

In the heritage of Roman Public speeches we can see three types of speeches: law court speeches (of prosecution and defense), politic speeches which were performed in the Senate or at other public 
meetings, and appraisal speeches which were not as frequent in Rome as they were in Ancient Greece.

In the 1-st century B.C. Rome was as well-developed in the terms of culture and knowledge as Greece and even influenced the latter in some ways. Due to the Roman Republic crisis, the art of political eloquence became really essential. Moreover, law court speeches turn out to be more important as a lot of trials had political background.

The most famous public speakers of the time were brothers Tiberius and Gaius Gracchus, especially the latter who even asked a flutist to accompany the speeches in order to amplify his voice. Gaius Gracchus's orations were distinguished by the intense emotional potential, persuasiveness, bright images and variety of speaking techniques. He was known for his rhetoric questions.

Though, most of the roman prominent speakers enjoyed this method of attention-getting, rhetoric questions were especially important for Gaius; in one of his speeches which he made after his brother's death he exclaims: "Where do I dash now, where do I turn to? To the Capitol? But it is soaked with my brother's blood. To the home of mine? To devastate my lamenting miserable and humiliated mother?"

Rhetoric questions addressing the listeners and various exclamations were abundantly used by public speakers afterwards. These "tools" are exploited by the modern lecturers and other orators, as well. Questions directs audience's attention to the essential information in the speech, make the listeners think the words of an orator over, analyze the data, they simplify the process of mental co-operation between a speaker and the audience. It is also effective to employ rhetoric phrases of addressing to the listeners. They help a speaker approach to the audience in a more personable way; allow him/her to keep the listener's attention.

Cicero, Marcus Tullius (106-43 B.C.), a famous Roman thinker and orator, was one of the best-educated people of his epoch. Cicero is considered one of the most significant rhetoricians of all time, charting a middle path between the competing Attic and Asiatic styles to become considered second only to Demosthenes among history's orators. His works include the early and very influential "De Inventione" (On Invention), "De Oratore" (a fuller statement of rhetorical principles in dialogue form), "Topics" (a rhetorical treatment of common topics, highly influential through the Renaissance), "Brutus" (Cicero) (a discussion of famous orators) and "Orator" (a defense of Cicero's style). Cicero also left a large body of speeches and letters which would 
establish the outlines of Latin eloquence and style for generations to come [6].

He championed the learning of Greek (and Greek rhetoric), contributed to Roman ethics, linguistics, philosophy, and politics, and emphasized the importance of all forms of appeal (emotion, humor, stylistic range, irony and digression in addition to pure reasoning) in oratory. But perhaps his most significant contribution to subsequent rhetoric, and education in general, was his argument that orators learn not only about the specifics of their case (the hypothesis) but also about the general questions from which they derived (the theses). Thus, in giving a speech in defense of a poet whose Roman citizenship had been questioned, the orator should examine not only the specifics of that poet's civic status, he should also examine the role and value of poetry and of literature more generally in Roman culture and political life. The orator, said Cicero, needed to be knowledgeable about all areas of human life and culture, including law, politics, history, literature, ethics, warfare, medicine, even arithmetic and geometry. For Cicero a public speaker is first of all a politician, so an orator's preparatory course should include the sum of knowledge necessary for the political career and ought to be based on the philosophical grounds.

He believes that the type of speech depends on the circumstance, background, situation in which the particular speech is made, so there are different "shades" of a speech. Perfect eloquence means that an orator is skillful in all types of speaking presented in traditional theory of Rhetoric. There are three main tasks an orator has to complete:

1) To prove his provisions;

2) To please the audience;

3) To influence their spirit.

Each of the tasks corresponds with one of the three basic styles: 1) the "discreet", calm (low) style is suitable for persuasion; 2) the "medium" style was created by the expressive sophists, and is characterized by elegance and sophistication, while the magnificent power of the 3 ) "grand" style captivates and charms a listener. The essence of an orator's skillfulness is his ability to use any of the styles when necessary, however, the most important is to attain the "grand" style.

Cicero's orations were full of exclamations, pleas, active gesticulation, appeals to the gods; he used rhythmic form of speech, combined seriousness and jokes, affectionate expressiveness and calm straightforwardness. His speeches were characterized with wit and 
vivacity. Cicero supposed the Art of public speaking to be the best tool of influence on the mass.

\section{Contemporary Trends in Public Speaking. Studies on Speech Communication in Europe and the USA in the $19^{\text {th }}-20^{\text {th }}$ centuries}

\section{1. Development of Rhetoric before the $19^{\text {th }}$ century}

Most of the academic disciplines, including rhetoric, derive from Ancient Greece. From that time rhetoric as the Art of speaking has gone a long way and has had to hold out a lot of modifications.

Rhetoric was first considered as the teaching about rules of making a speech that can impress the audience. At that time scholars came up with the conclusion that rhetoric existed alongside with philosophy, and what is more, these two subjects competed. Sophists claimed that the main goal of rhetoric was its practical outcome - to persuade a listener - no matter whether the orator's conclusions were truthful or false.

Generally, after Aristotle Rhetoric was used to define not only practical skills, but also to describe the set of theoretical rules and knowledge for the Art of public speaking.

Socrates argued that Rhetoric is not an art, but more a kind of a skill compared to a skill of a good cook. However, he also said that the final goal of public speaking was to persuade judges in the court, politicians at public meetings or citizens at the forums.

In the Middle Ages Rhetoric turned into a completely normative scholastic discipline which included the studies of the natural sources of beautiful speaking (natura oratora), learning the professional speaking skills (ars) and the training (exercitatio). Rhetoric included the theoretic knowledge on how to organize and structure the orations in accordance with the author's purposes and goals. It dealt with the art of argumentation and means of persuasive speaking. The emphasis was also placed on the rhetoric effects, techniques, pronunciation, body language and mimics.

At that period of time Rhetoric was one of the seven chosen arts. In the Renaissance Public Speaking was also a subject matter of some treatises.

Later scholars quite a few times claimed that rhetoric was subsidiary to philosophy. For example, R. Dekart , B. Spinoza, J. Locke did not think that rhetoric was a serious independent discipline. J. Locke supposed that communication was a spontaneous process and all the 
rhetoric figures resulted from the incomplete and imperfect nature of the peoples' language.

In the middle of the 19-th century studying Rhetoric was eliminated in most Universities of Europe which was caused by a number of sociopolitical and economic changes, orator's prose was replaced by the creative writing.

In the 19-th century Rhetoric went through the period of crisis. It was considered to be only the studies of eloquence and was not treated as a significant discipline. There were serious doubts as for the importance of Rhetoric for the society of that time. For instance, in $1844 \mathrm{~V}$. Belinskiy described rhetoric as the art of writing beautifully about something which the author didn't know a thing about.

As a result fewer books on Rhetoric were published at that time and rhetoric as a subject was eliminated from the curricula of the most universities. For about a hundred years Rhetoric, as an academic course, existed only in the religious institutions. At the same time rhetoric traditions were maintained in the majority of Western countries, where Rhetoric at that time was studied as a part of some other disciplines, for instance, public speaking, linguistics, and others.

Thus, Rhetoric lost its importance for some generations, which could not happen without negative effects. In our country it caused a dramatic decline in speaker's potential and orator's expertise of specialists in both Science and the Humanities. It is highly unfavorable for a new democratic state (which Ukraine is), where communication becomes more and more essential in all areas of public interaction - judicial, socio-political, academic, religious etc.

It is known, that Rhetoric is celebrated in any country at the times subsequent to the periods of economic or governmental conflicts, of the reformations, when the society has just found the solutions to some problems. That is why soon after the period of rejection; Rhetoric becomes interesting for the thinkers in the USA and Eastern and Western Europe again.

Within the latest decades the interest to rhetoric has been restored, this was first of all brought about by the growing significance of politics in the life of society. Public felt the need for educated and eloquent politicians, lawyers, lecturers that could persuade their listeners and make the ideas they present accepted by the audience. Moreover, in the jobs that involve teaching, acting, working with customers people faced increasing competition, when those who could speak well got the 
advantage. The number of professionals who want to study rhetoric has been steadily growing in most of the democratic states.

That is why nowadays teaching students of different specializations the Art of speaking in public is a vital aspect of training undergraduates for their professional future, where public speaking is an important part of personal development and self-education.

\subsection{Neo-rhetoric}

In the second half of the 20-th century most of the academic disciplines accept anthropocentric paradigm of the research. Thus the interest to speech as the means of people's communication helped to renew the popularity of Rhetoric. At the same time, such new direction of language studies as semiology (theory of the signs) and structuralism appear. These two factors contribute to the formation of a new type of rhetoric - neo-rhetoric.

The term was coined in the 1950-ies by the Professor of the University of Brussels H. Perelman. Neo-rhetoric compiled the knowledge of linguistic, logic, philosophy, and in different countries the scholars studying rhetoric emphasized one particular of the abovementioned subjects. The representatives of neo- rhetoric suppose that any act of speaking has two goals - to inform and to influence; and any communication is rhetorical by itself. The pioneers of neo-rhetoric, Perelman defines Rhetoric as the theory of persuasive communication; this interpretation is based on Aristotle's understanding of Rhetoric as means of persuasion.

In France the Literary theorist Roland Barthes developed what is then became known as meta-rhetoric [2]. In his best known work "The Death of the Author" Barthes saw the notion of the author, or authorial authority, in the criticism of literary text as the forced projection of an ultimate meaning of the text. By imagining an ultimate intended meaning of a piece of literature one could infer an ultimate explanation for it. But Barthes points out that the great proliferation of meaning in language and the unknowable state of the author's mind makes any such ultimate realization impossible. As such, the whole notion of the 'knowable text' acts as little more than another delusion of the bourgeois culture. The author has to obey to the external laws, mysterious scenarios that are 
imposed by a language, so not a person uses a language, a language itself uses people.

The French neo-rhetoric tried to restore the ancient Greek and Ronan rhetoric traditions. However, unlike the traditional rhetoric, which was highly normative, French neo-rhetoric did not fix any strict norms. One of the key terms in neo-rhetoric is discourse. In the French new rhetorical studies it is seen as an artistic text; in Belgium new rhetoricians see a discourse as a coherent text analyzed in the light of pragmatic, sociocultural and psychological factors.

Within the last decades, the term discourse has become one of the central notions in Rhetoric and Linguistic in most European countries; discourse is a coherent text viewed with regards to the extra-linguistic pragmatic, social, psychological and cultural factors; it is a speech considered as a purposeful social act, as a component of people's interaction and of cognitive processes. The term discourse cannot be used with reference to ancient or historic texts, as they do not have direct connection with real life, extra-linguistic situation. On the one hand discourse is linked with a pragmatic situation, which is analyzed in order to assess its coherence and adequacy, or to interpret it. The "life" context of a discourse is structured in the form of "frames" (typical situations) or "scripts". Creation of different frames and scripts is an essential part of the theory of discourse. On the other hand, discourse deals with mental processes of the speakers: ethnical, psychological, social and cultural strategies of text production and interpretation (discourse processing); these strategies consider the circumstances which determine the pace of speech, level of its coherence, correlation between general facts and specifics, known and new information, the subjective and the common views etc. They prescribe which means to use in order to achieve the goal.

So, Rhetoric as the studies of discourse has evolved from the art of persuasive talking bordering with the art of deception to the art of critical thinking, when a speaker takes into consideration the historical, psychological and personal factors of any communication.

Generally, new Rhetoric is described by such features as: extensional characteristic - the potential audience is constantly growing, becoming as big as the whole mankind; intentional one - the range of topics of 
communication is almost unlimited; psychological - rhetoric is becoming more and more personal, intimate, it appeals not to all the audience but to each of them; political - rhetoric has become more liberal, available for the mass; gnoceologic - computer teaches us to organize our communication in a more rational way; demonstrative video aid introduced more non-verbal visual means of persuasion (indeed, "better seen told").

\subsection{Modern Visions of Rhetoric and the Art of Speaking}

U. Eco defines the main aspects of Rhetoric [7]. Firstly, it is the studies of the feature of an imperative discourse. Also, Rhetoric deals with making persuasive speeches, means of argumentation. Finally, rhetoric operates with some common techniques of effective speaking. The key feature of rhetoric is persuasive character of speaking.

Socrates accused the sophists of distorting the truth in favour of confident and persuasive talking. Yet, in the modern society, public speakers do not always strive for the truth struggling to make their speeches highly convincing and smooth. Politicians do not care much about the truthfulness of their arguments. Lawyers also place the emphasis on making the judges accept their points, i.e. on the persuasive aspect of a speech, although the main purpose of their oration is believed to be finding out the truth on a particular case. So, the aim of judicial speaking is actually to convince the listeners. Persuasive speaking is delivering a message that is intended to change a recipient's opinion, but the result of persuasion is a belief, and a belief is hardly ever based on pure knowledge (the truth). Judicial speaking is, however, restricted by the domain of Law, it has some distinctive features which we are going to speak about later.

Public speaking as a part of acting (drama) should always be persuasive. On the other hand, an actor does not concentrate on the truth, he/she does not think about the correspondences between his /her words and a real state of affairs. The key to an actor's success is the correlation between his/her feeling and the words that are pronounced from the stage. Remember, a famous "I don't believe it!" by Stanislavsky. An actor will hear it if he does not make the audience believe that he is feeling what he is talking about. The truth is not the final goal of acting; 
its purpose is make-believe impression of the truth, the things happening on the stage do not have to be the truth, they just have to look like the truth.

So, which conclusions can we make here? First of all, we should consider the ability of public speaking as the Art, the art of acting. Nobody doubts that in different types of talks in rhetoric - in public speaking, as well as in a judicial speech, or an academic lecture - there is one common basis, they are all very closely connected with drama, with the Art of speaking on stage. If we eliminate this common element - the essence which unites all these types with the Art of drama, will we still have any grounds to call Rhetoric an Art?

Then, speaking about Rhetoric as a subject, we should identify the differences between the central terms: language and speech. Language is the structure that enables us to make texts and understand them. Speech is the implementation of this system, the texts that we create and comprehend. The text is a verbal field; it exists as the combination of speech and written use of language.

Public speaking allows us to study the use of language in practice, to make some generalizations and accumulate the knowledge of the most flourishing representatives of public communication.

In the modern world rapid growth of interest to public communication was caused by many factors among. First of all, now we are all living in the "knowledge society" where, unlike in the previous centuries, the vast majority of people make their living doing intellectual (not manual, physical) work, so a word as a "tangible" cover of knowledge is more important that it has ever been. Secondly, the competitive nature of marketing economic raised the value of an effective word. Most successful people have one thing in common: they can speak.

However, the advance of modern information technology has made exchanging information a fast and simple process. At the same time, this jeopardized the Art of Speaking by replacing face to face conversation with all kinds of social network sites, text messaging and e-mails. So, nowadays we need to make more effort to preserve the genuine art of giving a meaningful, informative and expressive talk. Thus, successful speaking is taught all over the world. 
In Ukrainian academic tradition, the Art of speaking has been studied within the scope of Rhetoric - the subject teaching to compose, deliver and use a speech appropriately. Classical Rhetoric includes Oratsoric (epideictic speaking) and Homiletic (didactic speaking, clerical speaking).

In the USA the art of speaking is studied within a special course called Speech Communication. It is a separate independent sphere of knowledge which involves educational institutions, departments in colleges and universities, on which a wide range of research works and reference materials, as well as professional journals, are published. The subject embraces studying Rhetoric, Public Speaking, Artistic recital, Literature Interpretation, Drama, Directing, analysis of the sample orations etc. The structure elements of the Public Speaking theory in the USA are: composing speeches, presentation of speeches, types of speeches etc.

Speeches are classified according to the speaker's intention, goal, not on the basis of the sphere of communication (political, clerical, judicial, academic etc.), as it used to be in classic tradition. For instance, A. Monroe distinguishes speeches to inform (e.g. definitional and instructional speeches), and speeches to persuade and actuate (speeches of reinforcement, modification and actuation) [9, p. 295].

In the American books on Public Speaking typology of speeches is accompanied with very detailed descriptions of principles of speechmaking, as well as recommendations and guidelines on how to create a successful speech of one or another particular type.

The emphasis is placed on using a person's voice and body to communicate. The human voice is the physical instrument that shapes the meanings of words and ideas. According to the modern American theory of Public speaking the manner of speaking and the speaker's moves should be absolutely natural, spontaneous. Memorizing and overpracticing is not approved of. However, learning about the characteristic of vocal quality and acquiring some vocal skills helps make a speech more expressive and affect the listeners. For instance, A. Monroe says that monotonous speaking, like a drug, declines concentration and impedes understanding, while varied pitch and rate keep audience's attention, stimulate their interest. Speaking of the vocal qualities the 
American authors define such characteristics as volume, rate, pauses, and enunciation. They also notice that physical behavior (body language) help to express extra meaning and control listeners' understanding and attention.

\subsection{Neuro-Linguistic Programming}

Another contemporary branch of speech studies that is popular in most of the Western countries is called Neuro-Linguistic Programming (or NLP) [3]. This name encompasses the three most influential components involved in producing human experience: neurology, language and programming. The neurological system regulates how our bodies function, language determines how we interface and communicate with other people and our programming determines the kinds of models of the world we create. Neuro-Linguistic Programming describes the fundamental dynamics between mind (neuro) and language (linguistic) and how their interplay affects our body and behavior (programming).

NLP is a pragmatic school of thought - an 'epistemology' - that addresses the many levels involved in being human. NLP is a multidimensional process that involves the development of behavioral competence and flexibility, but also involves strategic thinking and an understanding of the mental and cognitive processes behind behavior.

NLP provides tools and skills for the development of states of individual excellence, but it also establishes a system of empowering beliefs and presuppositions about what human beings are, what communication is and what the process of change is all about. At another level, NLP is about self-discovery, exploring identity and mission. It also provides a framework for understanding and relating to the 'spiritual' part of human experience that reaches beyond us as individuals to our family, community and global systems.

NLP is not only about competence and excellence, it is about wisdom and vision. Through the years, NLP has developed some very powerful tools and skills for communication and change in a wide range of professional areas including: counseling, psychotherapy, education, health, creativity, law, management, sales, leadership and parenting. 


\section{Art of speaking publically in Ukraine}

\subsection{Truditions of Liberal Arts in Ukraine. \\ Public Talk in Kyiv-Mohyla Academy}

Ukrainian rhetoric tradition comprises the best of the public speaking heritage from Ancient Greece, Rome and Slavonic schools in Kyiv Russ.

The information about rhetoric works in Kyiv Russ is scarce; however, we can speak about Practical Rhetoric as the art of influence via the expressive and effective verbal means. For example, the work by K. Turovskyi (a prominent orator and representative of so called teacher's fine-speaking) "The Word on the new Sunday Following the Easter Day" is an illustration of a speech which was built due to the classical canons of the art of rhetoric. The whole speech is based on the comparison of the delighted Christian church with the nature; just awaken at the beginning of spring. The author uses metaphors talking of the similarity between the believers and lambs, a preacher and a teacher whose task is to affect his disciples with a word. This oration is illustration of a light, radiant speech; K. Tirovskyi supposed that a speech should not be gloomy, but full of light and joy.

Formation and development of Ukrainian Rhetoric is connected with works by Mytropolit Makaryi, M. Spapharyi and educational movement in Orthodox Christian fraternal schools, where the youngsters were taught grammar, poetic, dialectic, music, arithmetic, languages and rhetoric. Those schools had been established at the end of the 16-th 17-th centuries. The best-known schools of that time were located in Lviv, Vil'no, Kyiv and Polotsk. The first guide books on speech making were created in such schools. One of the firs text -books on public speaking is supposed to be "The Tale of the Seven Free Wisdoms" which was the preliminary course for those who intended to enter high schools at that time; and contained some information on grammar, music, geometry, astronomy and rhetoric. Rhetoric was regarded to be one of the superior subjects; and students were allowed to study it only on completing the course in grammar, reading, music, basics of the Greek and Old Slavonic languages etc. In the 17-th century such texts as "The Tale..." were not only read but also performed on the stage (e.g. in Kyiv Seminary) for some special occasions. Thus, so called 
"school drama" starts to develop. The orators, for instance Petro Mohyla, begin to use theatric performance as a method of teaching rhetoric and poetics.

The author of the first "Rhetoric" written in our country remained unknown; in fact, it was not his original writing but only the interpretation of the work by a German thinker F. Melanchthon. It contained two books: "On the case invention" and "On the word adornment"; the ideas of the book were presented in form of a dialogue between a teacher and a student.

Rhetoric in the 17-th century mainly followed the footstep of the Ancient tradition, however, a new component - didactic (teaching) speech, was added, the scholar and clerical rhetoric were united under the title of "homiletic". In the 17-th century Kyiv Mohyla academy, which was founded in 1632, became the centre of education in Ukraine; 127 books on Rhetoric that were used at the academy are still preserved in the archives, mostly they were written in Latin. Among them are: "The Orator Of Mohyla" (1635-1636) by I.Kpnonovych- Gorbatskyi, "The Chamber of Tullius' Eloquence” (1683) by I. Krokovskyi, “On the Art of Rhetoric" (1706) by Th. Prokopovitch.

An important role in the development of Ukrainian Public Speaking was played by the rector of Kyiv-Mohyla Academy Ioanikyi Galiatovskyi (his work is "The Brief Science or on the Means of Writing a Speech"). He defined the reasons for studying Rhetoric, such as: 1) in sake of the Ancient time, 2) for dignity, 3) in sake of the truth, 4) for pleasure (words can beautify), 5) for usefulness. The tasks which were attributed to rhetoric works of the time were:

1) to teach a person to consider, to compose a speech, to garnish it and to learn to express the ideas by means of a clear (light) speech;

2) a speaker had to demonstrate himself as an individual of a particular nature, because the personality of a speaker was of great importance (moral aspect);

3 ) the texts that helped to learn the art of word were recommended, the speeches of congratulation, political debate and others were presented; the issues that were actual at the time were held;

4) the competitions in epistolary art were organizes, the great attention was paid to the style of writing. 
In 1708-1709 the course of Rhetoric in Kyiv- Mohyla Academy was read by Theophan Procopovich. He divided his course into such parts as: 1) introduction to the speech (the first phrase effect), 2) substantiations (teaching how to formulate the proofs), 3) material arrangement, 4) speaking style (format of speech), 5) feelings and emotions, 6) historical aspect of the issue, 7) types and kinds of speeches, 8) epideictic speech, 9) clerical speech, 10) memorizing a speech and performance or delivery of a speech. Here we should notice that some of these aspects (such as importance of the introduction, typology of speeches, arrangement of the facts, memorizing techniques etc.) are regarded as essential and described in detail in the majority of modern work on Public Speaking.

Th.Prokopovich thought that Rhetoric does not have distinct limits of its subject, as it has supplementary functions. The Art of Speech helps to find and give answers to many questions in various spheres of knowledge and can even change an opponent's opinion.

I. Kononovich- Gorbatskyi taught rhetoric, dialectics and logic in the Academy. The area of his interests included such issues as: Is rhetoric a kind of Art? What do an orator's tasks include? He knew the Ancient Rhetoric well and believed that the most important qualities of an orator are activeness, ability to react to the current events, to raise the questions which would make the people interested. He gave tips on how to compose greeting and farewell speeches.

\subsection{On the Issue of Public Speaking in Modern Ukraine}

In the 17-18-th centuries Rhetoric in Ukraine developed on the basis of teaching Antique and Western-European public speaking traditions as a part of school education.

And in the beginning of the $19^{\text {th }}$ century the tradition of teaching Rhetoric as a subject gradually declines in most European Universities, and thus in Ukraine public speaking as an academic subject gives way to prosaic fictional writing. The number of educated people who can not only speak well but also teach the others to speak declined during the period of more than 150 years.

In the $20^{\text {th }}$ century development of public speaking was defined by the Soviet ideology, spontaneous or artistic speech presentation was 
replaced by making unnatural text aimed on promoting the political ideas of the ruling party.The method of the Soviet orators, which most of public speech presentation were based on, involved learning the whole speech by heart and giving the word for word presentation. This method had an obvious disadvantage: it was difficult to deliver your speech sincerely and emotionally when the speaker concentrated too hard on recalling the exact sentences of the script.

With the advance of the new era of ICT and development of new means of communication people faced the danger of "getting out of use" of speaking well. In Ukraine these major changes coincided with the crucial political change: decline of the previous political regime and getting the status of an independent state. On the one hand, the bureaucratic slang of soviet leaders that filled the sphere of public speaking for years and years was consigned to oblivion, and nothing was invented to fit in that niche. On the other hand, numberless borrowed words rapidly entered the speech of ordinary Ukrainians, as well as of famous politicians and other public people. And if in the past epochs the process of assimilation of newly borrowed lexis took years and allowed speakers to find for it the right place, nowadays, abundant "lexical foreigners" often make orators' presentations sound at least unnatural, not to say awkward.

What is more, the post-soviet linguistic space encountered another problem: so called "swear vocabulary" which used to be tabooed in the past, changed its status of language of villains and became commonly used both in common speech and in public speaking situations. It is obvious that when there is a gap and people have nothing decent to complete this gap with, it will be filled with some worthless substratum. So, public speeches of our modern orators are often a silly mixture of post-soviet clichés with the excess of borrowed words that not every listener will understand and a couple of "strong words".

In such circumstances, it is vital to develop liberal art education and create solid courses in public speaking that are aimed on teaching young people speaking in the conditions of our country taking into account the requirements of modern life.

\section{SUMMARY}

The article deals with the issues of history of Rhetoric and problems that public speaking as one of academic disciplines and liberal arts has faced in Ukraine. The author outlines the main historical stages of development of the Art of speechmaking, and demonstrates how they 
resulted in the modern trends in Rhetoric. The peculiarities of modern Ukrainian public speaking are also described, the necessity for studying Public Speaking as academic subject is highlighted.

\section{REFERENCES}

1. Аверинцев С. С. Риторика и истоки европейской литературной традиции. - М.: Языки русской культуры, 1996. - 447 с.

2. Барт Р. Избранные работы: Семиотика. Поэтика: Пер. с фр. M., 1989.

3. Макдермот Я., Яго В. Практический курс НЛП. М.: Эксмо, 2006. -464 c.

4. Овчинникова А.П. П'ять кроків до гарної мови: Мовна комунікація: Техніка мовлення/ А.П. Овчинникова. - Фенікс, 2008.$192 \mathrm{c.}$

5. Овчинникова А.П. Цінності культури та цивілізація: Вибрані праці. / А.П. Овчинникова. - Одеса: Юридична література, 2008. $288 \mathrm{c}$.

6. Цицерон М. Т. Три трактата об ораторском искусстве. Марк Туллий Цицерон; пер с лат. и прим. М.Л.Гаспарова . - М.: Научноиздательский центр “Ладомир”, 1994. - 475 с.

7. Эко У. Отсутствующая структура. Введение в семиологию: пер. С итал. - С. Пб. Петрополис, 1998.- 431с.

8. Fletcher L. How to Speak Like a Pro/ L. Fletcher- New York: Ballantine Books, 1996. -240 p.

9. Principles and Types of Speech Communication/ Rayme, McKerrow. -14 th edition. - Longman, 2000. -434 p.

10. Zeoli R. Seven Principles of Public Speaking/ R.Zeoli. Skyhorse Publishing, 2008. - 216 p.

Information about the author:
Ovchynnikova A. P.,
Doctor of Arts, Professor,
of Art and liberal arts department 33, Fontanska Road St., Odessa, 65009, Ukraine 